\title{
Insecticidal effect of ethnobotanical plant extracts against Anopheles arabiensis under laboratory conditions
}

\author{
Desta Ejeta* ${ }^{*}$, Ansha Asme and Animut Asefa
}

\begin{abstract}
Background: The emergence and spread of resistant strains of malaria vectors to chemical insecticides are becoming major problems for malaria vector management. Natural plant products have a vital role to play in the current challenge of malaria control. The current study was conducted to evaluate insecticidal effect of ethnobotanical plant extracts against the primary malaria vector, Anopheles arabiensis in northwestern Ethiopia.
\end{abstract}

Methods: Primarily, ethnobotanical plants used for Anopheles mosquito control were surveyed in Dangur district, northwestern Ethiopia. Insecticide-susceptible strains of Anopheles arabiensis mosquito were reared in the insectary of the Tropical and Infectious Diseases Research Centre, Assosa University. After surveying plants used for mosquito control in local people, four frequently used plants were identified for extraction. The larvicidal and adulticidal potential of frequently used plant extracts against susceptible strains of the laboratory colony were evaluated.

Results: A total of 15 plants were identified as ethnobotanical plants that help local people with mosquito control. Azadirachta indica, Ocimum lamiifolium, Ocimum americanum, Moringa olifeira leaf, and Moringa olifeira seed species of local plants were found to be frequently used to kill and/or repel mosquitoes in the study district. All the plant extracts were found to have potential larvicidal activity against fourth instar larvae of An. arabiensis and only ethanol and methanol extract of Azadirachta indica and Ocimum lamiifolium were found to have potential adulticidal effect against adult of An. arabiensis. The highest larvicidal activity was observed in ethanol extract of Azadirachta indica with 95\% larval mortality and lowest Lethal Concentration 50 (LC 50) of 40.73parts per million (ppm) and LC90 of $186.66 \mathrm{ppm}$. The highest adulticidal activity was observed in methanol extract of Azadirachta indica with 75\% adult mortality at 300 ppm and lowest LC50 of 106.65 ppm and LC90 of 1,293 ppm. The lowest larvicidal and adulticidal activity was observed in methanol extracts of Ocimum lamiifolium with $63.35 \%$ larval mortality and leaf extract of Moringa olifeira with $50 \%$ adult mortality at 300 ppm, respectively.

Conclusion: Ethanol extract of Azadirachta indica exerted a remarkable larvicidal effect against An. arabiensis and thus it can be used for botanical mosquito insecticide development. Since the current finding is based on susceptible strain of An. arabiensis, further work on wild mosquitoes is recommended.

Keywords: Anopheles arabiensis, Botanical insecticide, Dangur, Ethnobotanicals, Malaria

*Correspondence: desta.ejeta@yahoo.com

Department of Biology, College of Natural and Computational Science,

Assosa University, Assosa, Ethiopia

\begin{abstract}
Background
Anopheles arabiensis is the principal malaria vector in Ethiopia, having a wide distribution while Anopheles pharoensis, Anopheles funestus, Anopheles nili, and Anopheles stephensi have a secondary role in malaria transmission in the country [1-3]. Vector control is a
\end{abstract} original author(s) and the source, provide a link to the Creative Commons licence, and indicate if changes were made. The images or other third party material in this article are included in the article's Creative Commons licence, unless indicated otherwise in a credit line to the material. If material is not included in the article's Creative Commons licence and your intended use is not permitted by statutory regulation or exceeds the permitted use, you will need to obtain permission directly from the copyright holder. To view a copy of this licence, visit http://creativecommons.org/licenses/by/4.0/. The Creative Commons Public Domain Dedication waiver (http://creativeco mmons.org/publicdomain/zero/1.0/) applies to the data made available in this article, unless otherwise stated in a credit line to the data. 
crucial prevention tool to mitigate the disease. Long-lasting insecticidal nets (LLINs) and indoor residual spray (IRS) are among the most effective malaria vector management strategies recommended in Africa. However, the wide spread of insecticide-resistant strains of Anopheles is challenging chemical insecticide-based malaria control strategies. Insecticide susceptibility tests carried out in Ethiopia have shown different levels of resistance by the principal vector to insecticides in use for IRS and/or to treat LLINs $[4,5]$. For these reasons, looking for an alternative is becoming of major interest to scientists and policymakers working in the area.

Traditionally or culturally, different communities use different plants in various forms to protect themselves against mosquitoes and other insect bites [6,7]. Naturally occurring compounds and their derivatives are of increasing interest for the development of new insecticidal compounds against malaria vectors. Plants possess a wide range of bioactive phytochemicals that are selective, biodegradable and have minor or no adverse effects on non-target organisms and the environment [8]. Reports indicate that essential oils and extract of local plants have a promising larvicidal, adulticidal and repellent activity against malaria vectors $[9,10]$. Gathering information about ethnobotanical plants used in a particular society and evaluating efficacy is important. The main objective of the present study was to investigate the insecticidal effect of ethnobotanical plant extracts against An. arabiensis under laboratory conditions.

\section{Methods}

\section{Study area}

Ethnobotanical collection was conducted in three purposively selected villages: Manbuk 01, Kitil and Adipopo, Dangur district, northwestern Ethiopia. Dandur district is situated $687 \mathrm{~km}$ from the capital city, Addis Ababa, in northwest Ethiopia (Fig. 1). The district has an estimated total population of 68,653 . Geographically, the district lies at latitude and longitude of $11^{\circ} 30^{\prime} \mathrm{N}$ and $35^{\circ} 50^{\prime} \mathrm{E}$, respectively, with elevation ranging from 672 to $2731 \mathrm{~m}$ above sea level. Based on the information from metrological data in 2021, the area has mean annual rainfall ranging from 700 to $1400 \mathrm{~mm}$ per year and mean annual temperature ranging from $26-35^{\circ} \mathrm{C}$ per year.

\section{Ethnobotanical data collection techniques}

Semi-structured interviews were prepared for inhabitants/key informants of the three villages (Manbuk 01, Kitil, Adipopo) and were used as a guide following Martin [11]. A total of 20 key informants were identified

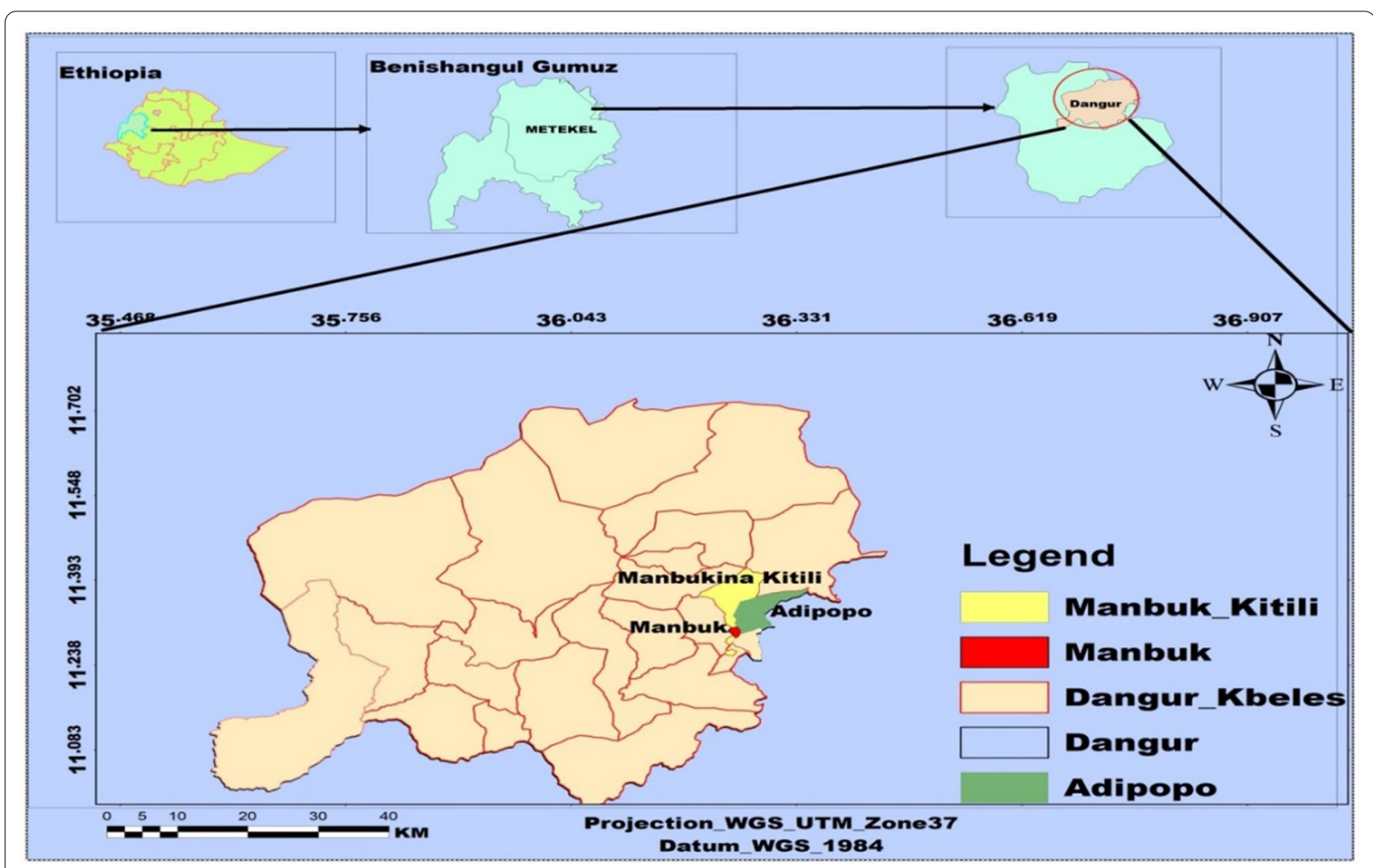

Fig. 1 Map of the study area 
based on the recommendations of local authorities and knowledgeable elders who were suggested by respective village elders. Key informants were interviewed to identify plants they use to repel and/or kill insects in general and mosquitoes in particular.

\section{Voucher specimen collection and identification}

Voucher specimens of the reported plants as repellant against mosquito vectors were collected and identified with taxonomic keys [12].

\section{Preparation of crude plant extracts}

Plant extraction was conducted in the microbiology laboratory, Assosa University. The leaves and seeds of the plants were washed thoroughly using clean water and air-dried under shade at room temperature for 15 days. The dried materials were ground separately to powder using a grinding mill. The powdered material was macerated with ethanol and methanol using Erlenmeyer flasks and placed on an orbital shaker at $60 \mathrm{rpm}$ at room temperature for $72 \mathrm{~h}$ [13]. The plant extract was filtered through cotton and subsequently with Whatman filter paper $(12.5 \mathrm{~cm}$ size). Filtrates were concentrated using a rotary evaporator to remove solvents from the extract. The crude extracts were collected in small volume beakers and kept in the freezer until used for mosquito efficiency tests.

\section{Mosquito rearing}

Larvae of An. arabiensis were obtained from the Tropical and Infectious Diseases Research Centre's insectary laboratory, Assosa University. Mosquitoes were reared using standard procedures and maintained at $25 \pm 2{ }^{\circ} \mathrm{C}$ temperature and $80 \pm 10 \%$ relative humidity and $12: 12$ light and dark photoperiod. Larvae were fed with yeast a 3:1. When pupae were formed, no food was supplied, and they were transferred to a cup that contained water by disposable pipettes and put in screened cages for adult emergence. The adults were fed on $10 \%$ glucose solution soaked in cotton pads, in addition to an animal (rabbit with shaved back and belly) blood meal given to the females twice per week. A petri dish lined with a moist cotton piece and covered with filter paper was put inside each cage for egg laying [14], which ensured that fourth instar larvae and 2-5 days old adult mosquitoes were continuously available for different bioassay tests.

\section{Larvicidal activity}

\section{Preparation of test and control solutions}

Two-hundred mg of the dried crude ethanol and methanol extract of each plant were placed in a standard measuring flask with distilled water to prepare $20 \mathrm{ml}$ of $1 \%$ stock solution; $0.1 \mathrm{ml}$ of Tween 80 was used as an emulsifier. From the $1 \%$ stock solution, concentrations of $50,100,150,200,250$, and $300 \mathrm{ppm}$ were prepared by adding the appropriate volume of dilution; $0.1 \mathrm{ml}$ of Tween 80 was made up to $100 \mathrm{ml}$ distilled water to serve as the negative control solution [14].

\section{Larvae bio-assay with crude leaf extract}

In the first phase of bio-assay, mosquito activity to frequently used plants, ethanol and methanol of crude extracts of the leaves and seed, were screened at $300 \mathrm{ppm}$ concentration. Batches of 20 fourth instar larvae of $A n$. arabiensis were transferred using a dropper to $200 \mathrm{ml}$ glass beakers each containing $100 \mathrm{ml}$ water and one batch as a negative control for each concentration. Each test was run three times. The test containers were held at $25 \pm 2{ }^{\circ} \mathrm{C}$ and $80 \pm 10 \%$ relative humidity with a photoperiod of $12 \mathrm{~h}$ light followed by $12 \mathrm{~h}$ dark. Larvae mortality was recorded after $24 \mathrm{~h}$ exposure in each concentration of test solutions [14].

\section{Determination of LC50 and LC90 of the crude leaf and seed extract of test plants}

Based on the preliminary screening, ethanol and methanol of the leaf and seed of plant extract was selected and subjected to dose-response bio-assay at concentrations of 50, 100, 150, 200, 250 and $300 \mathrm{ppm}$. The average mortality after $24 \mathrm{~h}$ was recorded and used to determine LC50 and LC90 values [14].

\section{Adulticidal activity \\ Adult bio-assay with crude leaf extract}

The triplicate series contained 20 females of $\mathrm{An}$. arabiensis in each tube. In the first phase of bio-assay, the mosquito activity of ethanol and methanol crude plant extracts was screened at $300 \mathrm{ppm}$ concentration. This concentration was impregnated into filter papers $(12 \times 15 \mathrm{~cm})$. Distilled water only was used as a negative control. The impregnated papers were air-dried for $5 \mathrm{~min}$ and then inserted into an exposure tube in the WHO testing kit. Twenty 2-5 days old, blood-starved, female mosquitoes were introduced into the holding tube and held for $1 \mathrm{~h}$ to acclimatize. The mosquitoes were transferred by gentle blowing in the exposure tube. After $1 \mathrm{~h}$ in the exposure tube, mosquitoes were transferred back to the holding tube to recover. A pad of cotton soaked with $10 \%$ glucose solution was placed on the mesh screen to feed recovering experimental and control mosquitoes. At the end of the $24 \mathrm{~h}$ recovery period, mosquito mortality was recorded and the percentage mortality was calculated [15].

Percentage of mosquito mortality was calculated by using the formula: 
Percentage of mortality $=\frac{\text { Number of dead mosquitoes }}{\text { number of mosquitoes tested }} * 100$

\section{Determination of lethal concentration 50 and lethal concentration 90 of the crude leaf extracts of test plants}

Based on the preliminary screening, ethanol and methanol leaf of plant extract was selected and subjected to dose-response bio-assays at concentrations of 50, 100, 150, 200, 250 and $300 \mathrm{ppm}$. The average mortality after $24 \mathrm{~h}$ was recorded and used to determine LC50 and LC90 values [14].

\section{Phytochemical screening of methanol and ethanol of crude extracts of test plants}

Crude methanol and ethanol extracts of all test plants were subjected to test the presence of major secondary metabolites (alkaloids, flavonoids, terpenoids, tannin, saponin, phenols following the procedures described by Madike et al. [16] and Bandiola et al. [17].

\section{Data analysis}

Data from all replications were pooled and mean per cent mortalities of larva and adult mosquitoes treated with crude leaf extract of the plants were determined by analysis of variance (ANOVA) using SPSS version 20. Fishers Least Significant Difference (LSD) was used to investigate statistical significance between the different test plants against mosquito mortality. The difference between means was considered statistically significant at $P<0.05$. The LC50\% and LC $90 \%$ and other statistics at 95\% fiducial limit of lower confidence limit and upper confidence limit and Chi-square values were determined using dosage mortality probit regression analysis of SPSS program version 20 to determine their larvicidal and adulticidal efficacies [14].

\section{Results}

\section{Ethnobotanical plant species used to repel mosquitoes} in the study area

A total of 15 plant species used to prevent mosquito bites were collected and identified from the study area (Table 1). From all plant species collected and identified, the most frequently used plants (Azadirachta indica (75\%), Ocimum lamiifolium (65\%), Ocimum americanum (70\%), leaf of Moringa olifeira (50\%), and seeds of Moringa olifeira (50\%)) were selected to test their larvicidal and adulticidal effects against An. arabiensis.

\section{Larvicidal activity of crude leaf and seed extracts of test plants}

The highest mortality was recorded in ethanol leaf extract of Azadirachta indica (95\%). Methanol leaf extract of
Ocimum lamiifolium recorded the lowest activity with mortality of $63.35 \%$ (Table 2 ). There was no statistically significant $(\mathrm{p}>0.05)$ difference in the larvicidal potential between ethanol and methanol extract of Moringa olifeira leaf and Moringa olifeira seed. However, there was a significant difference $(\mathrm{p}<0.05)$ in the larvicidal efficacy between ethanol and methanol leaf extracts of Azadirachta indica, Ocimum lamiifolium, and Ocimum americanum.

\section{Determination of LC50 and LC90 of leaf and seed crude plant extract}

Ethanol leaf extract of Azadirachta indica, Ocimum lamiifolium, Ocimum americanum, and methanol extract of Moringa olifeira leaf and Moringa olifeira seed were subjected (Table 3). Ethanol leaf extract of Azadirachta indica caused the highest larvicidal activities against the fourth instar larvae of An. arabiensis with the lowest LC50 of 40.73 ppm and LC90 of 186.66 ppm. Ethanol crude leaf extract of Ocimum americanum showed the relatively highest LC50 and LC90 (LC50 = 92.42 ppm, LC90 $=551 \mathrm{ppm}$ ).

\section{Adulticidal activity of crude leaf and seed extracts of test plants}

The highest mortality was recorded in methanol leaf extract of Azadirachta indica (75\%) (Table 4). However, the ethanol and methanol leaf extract of Moringa olifeira was found to have lowest mortality at 50\% (Table 4). There was no statistically significant $(\mathrm{p}>0.05)$ difference in the adulticidal potential between ethanol and methanol extract of all test plants. However, there was a significant difference $(\mathrm{p}<0.05)$ in the adulticidal efficacy between ethanol leaf extracts of Azadirachta indica and Ocimum americanum and between ethanol leaf extracts of $A$. indica and $M$. olifeira leaf and between ethanol leaf extracts of $A$. indica and seed extract of $M$. olifeira.

\section{Determination of LC50 and LC90 of crude leaf plant extracts}

Methanol leaf extract of Azadirachta indica caused the lowest LC50 of 106.655 ppm and LC90 of 1,293 ppm and ethanol crude leaf extract of Azadirachta indica showed the highest LC50 and LC90 (LC50=151.033 ppm, LC90 = 1059 ppm) (Table 5).

\section{Phytochemical screening of methanol and ethanol crude leaf and seed extracts of test plants}

Phytochemical screening was conducted for all methanol and ethanol crude plant extracts to test the presence of alkaloids, flavonoids, terpenoids, tannin, saponin, and phenols; the results are presented on Table 6. 
Table 1 Plant species collected from the three villages of Dangur district

\begin{tabular}{|c|c|c|c|c|c|}
\hline Scientific name & Vernacular name & Family name & Plant type & $\begin{array}{l}\text { Part used and methods of } \\
\text { application }\end{array}$ & $\begin{array}{l}\text { Usage } \\
\text { frequency } \\
(\%)\end{array}$ \\
\hline Allium sativum L. & Nech Shenkurt (A) & Alliaceae & Herbs & $\begin{array}{l}\text { Crushing } 3-5 \text { bulbs and applying } \\
\text { juice to the body }\end{array}$ & 5 \\
\hline Azadirachta indica A. & Meem(A)Lemima(G) & Meliaceae & Tree & 10-15 leaves put in the house & 90 \\
\hline Carica papaya L. & Papayaa(A) & Caricacae & Tree & $\begin{array}{l}5 \text { leaves crushed and apply juice } \\
\text { to exposed parts of the body }\end{array}$ & 10 \\
\hline Citrus sinensis $\mathrm{L}$. & Birtukan(A) & Rutaceae & Tree & $\begin{array}{l}\text { Fruit peeled and burned to gener- } \\
\text { ate smoke }\end{array}$ & 15 \\
\hline $\begin{array}{l}\text { Crotonmacrostachyus Hochst. Ex } \\
\text { Del. }\end{array}$ & Bissana(A) & Euphorbiaceae & Tree & $\begin{array}{l}\text { Burn 8-10 dried leaves to gener- } \\
\text { ate smoke }\end{array}$ & 5 \\
\hline Cymbopogon citratus Stapf. & Tej $\operatorname{sar}(A)$ & Poaceae & Herb & $\begin{array}{l}\text { Burn } 10 \text { of leaf plant to generate } \\
\text { smoke }\end{array}$ & 10 \\
\hline Echinops keberich Mesfn. & $\begin{array}{l}\text { Kebericho(A) } \\
\text { Asitana(G) }\end{array}$ & Asteraceae & Herb & $\begin{array}{l}3 \text { dried root parts burned to } \\
\text { generate smoke }\end{array}$ & 25 \\
\hline Eucalyptus globulus L. & Nech bahirzaf(A) & Myrtaceae & Tree & $\begin{array}{l}\text { Burn whole plant to generate } \\
\text { smoke }\end{array}$ & 10 \\
\hline Eucalyptus camaldulensis Dehn. & Key beharzaf(A) & Myrtaceae & Tree & $\begin{array}{l}\text { Burn whole plant to generate } \\
\text { smoke }\end{array}$ & 10 \\
\hline Moringa olifeira L. leaf & $\begin{array}{l}\text { Sheferaw(A) } \\
\text { Chehwie(G) }\end{array}$ & Moringaceaea & Tree & $15-20$ leaves put in the house & 50 \\
\hline Moringa olifeira L. seed & $\begin{array}{l}\text { Sheferaw(A) } \\
\text { Chehwie(G) }\end{array}$ & Moringaceaea & Tree & $\begin{array}{l}20-30 \text { seeds crushed and rubbed } \\
\text { on skin }\end{array}$ & 50 \\
\hline $\begin{array}{l}\text { Ocimum lamiifolium Hochst, ex } \\
\text { Benth. }\end{array}$ & Damakasse(A)Akawaya(G) & Lamiaceae & Shrub & $\begin{array}{l}\text { About } 5 \text { leaves-juice applied to } \\
\text { the skin }\end{array}$ & 65 \\
\hline Ocimum americanum L. & $\begin{array}{l}\text { Yezenjero Zekakebie(A) } \\
\text { Omasiya(G) }\end{array}$ & Lamiaceae & Shrub & $\begin{array}{l}\text { About } 5 \text { leaves-juice applied to } \\
\text { the skin }\end{array}$ & 70 \\
\hline Olea europaea L. & Woira(A) & Oleaceae & Tree & $\begin{array}{l}3 \text { stem parts of plant burned to } \\
\text { generate smoke }\end{array}$ & 20 \\
\hline Otostegia integrifolia Benth. & Tnjut(A) & Lamiaceae & Shrub & Dry 10 leaves and smoke & 25 \\
\hline Ruta chalepensis L. & Tena Adam (A) & Rutaceae & Herb & $\begin{array}{l}\text { Thermal expulsion and direct } \\
\text { burning of seeds }\end{array}$ & 20 \\
\hline
\end{tabular}

A Amharic, G Gumzegna

Table 2 Larvicidal activity of ethanol and methanol crude leaf and seed plant extract of test plants against fourth instar of larvae of Anopheles arabiensis at 300 ppm

\begin{tabular}{lcr}
\hline \% Mean mortality \pm SE & & \\
\hline Plant species & \multicolumn{2}{l}{ Solvent } \\
\cline { 2 - 3 } & Ethanol & Methanol \\
\hline Azadirachta indica & $95 \pm 0.577^{\mathrm{Aa}}$ & $65 \pm 1.528^{\mathrm{Ba}}$ \\
Ocimum lamiifolium & $90 \pm 0.577^{\mathrm{Aab}}$ & $63.35 \pm 3.480^{\mathrm{Bab}}$ \\
Ocimum americanum & $88.25 \pm 0.333^{\mathrm{Aabc}}$ & $76.65 \pm 0.667^{\mathrm{Babc}}$ \\
Moringa olifeira leaf & $86.65 \pm 0.667^{\mathrm{Abc}}$ & $91.65 \pm 0.882^{\mathrm{Ac}}$ \\
Moringa olifeira seed & $83.35 \pm 0.333^{\mathrm{Abc}}$ & $90 \pm 0.557^{\mathrm{Ac}}$ \\
Negative Control & $0.00 \pm 0.000^{\mathrm{Ad}}$ & $0.00 \pm 0.000^{\mathrm{Ad}}$ \\
\hline
\end{tabular}

*Each value (\% mean $\pm S E$ ) represents mean value of three replicates

*Means followed by the same letters within the same row (Upper case) and within the same column (Lower case) are not significantly different $(p>0.05)$

\section{Discussion}

A total of 15 local plant species were identified used for mosquito control in Dangur district. The presence of several plant species used for mosquito control by local people is a good indication of the deep-rooted culture of local plants in the study area. This result is similar to other studies of two plants conducted in Ethiopia [18, 19]. The current results show that local communities had indigenous knowledge and give emphasis to using local plants to repel mosquitoes. Out of all local plant species used for mosquito control the most frequently used were Azadirachta indica (75\%), Ocimium lamiifolium (65\%), Ocimium americanum (70\%), leaf of Moringa olifeira (50\%), and seeds of Moringa olifeira (50\%). Some of the repellant plants recorded in the current study have been reported in other parts of Ethiopia [9, 20, 21]. 
Table 3 LC50 and LC90 of test plant extract against larvae of Anopheles arabiensis

\begin{tabular}{lllllllll}
\hline Solvent & Plant name & LC 50 & $\mathbf{L C L}$ & $\mathbf{U C L}$ & $\mathbf{L C} \mathbf{0}$ & $\mathbf{L C L}$ & $\mathbf{U C L}$ & $\mathbf{X}^{\mathbf{2}}\left(\mathbf{d} \mathbf{d f}^{\mathbf{b}}=\mathbf{4}\right)$ \\
\hline Ethanol & Azadirachta indica & 40.73 & 10.38 & 65.31 & 186.66 & 131.97 & 378.50 & 0.339 \\
& Ocimum lamiifolium & 40.93 & 5.35 & 69.23 & 230 & 170.5 & 944.18 & 0.744 \\
& Ocimum americanum & 92.42 & 45 & 129.22 & 551 & 318 & 3092 & 1.419 \\
\multirow{2}{*}{ Methanol } & Moringa olifeira leaf & 45.43 & 11.93 & 72 & 260 & 159 & 558 & 0.390 \\
& Moringa olifeira seed & 62.35 & 19.1 & 94.01 & 388 & 239.75 & 1792.11 & 2.831 \\
\hline
\end{tabular}

* LC50-Lethal concentration kills 50\% of the exposed larvae LC90-Lethal concentration kills $90 \%$ of the exposed larvae UCL Upper confidence limit LCL Lower confidence limit $X^{2}$ Chi-square $d f$ degree of freedom

Table 4 Adulticidal activity of ethanol and methanol crude plant extract of test plants against adult of Anopheles arabiensis at $300 \mathrm{ppm}$

\begin{tabular}{lll}
\hline \% Mean mortality \pm SE & & \\
\hline Plant species & \multicolumn{2}{l}{ Solvent } \\
\cline { 2 - 3 } & Ethanol & Methanol \\
\hline Azadirachta indica & $71.65 \pm 0.333^{\mathrm{Aa}}$ & $75 \pm 0.577^{\mathrm{Aa}}$ \\
Ocimum lamiifolium & $70 \pm 0.577^{\mathrm{Aa}}$ & $65 \pm 1.201^{\mathrm{Aa}}$ \\
Ocimum americanum & $55 \pm 0.577^{\mathrm{Ab}}$ & $51.5 \pm 0.333^{\mathrm{Ab}}$ \\
Moringa olifeira leaf & $50 \pm 0.577^{\mathrm{Ab}}$ & $50 \pm 0.577^{\mathrm{Ab}}$ \\
Moringa olifeira seed & $55 \pm 0.881^{\mathrm{Ab}}$ & $53.3 \pm 1.4529^{\mathrm{Ab}}$ \\
Negative Control & $0.00 \pm 0.000^{\mathrm{Ac}}$ & $0.00 \pm 0.000^{\mathrm{Ac}}$ \\
\hline
\end{tabular}

* Each value (\% mean \pm SE) represents mean value of three replicates

* Means followed by the same letters within the same row (Upper case) and within the same column (Lower case) are not significantly different $(p>0.05)$

All the test plants were found to have potential larvicidal activities against the fourth instar larvae of An. arabiensis at the test concentration. The highest mortality was recorded in ethanol leaf extract of Azadirachta indica, the methanol leaf extract of
Moringa olifeira, the ethanol leaf extract of Ocimum lamiifolium, and methanol seed extract Moringa olifeira. However, the methanol leaf extract of Ocimum lamiifolium, Azadirachta indica, Ocimum americanum followed by ethanol seed extract of Moringa olifeira, the leaf extract of Moringa olifeira, and leaf extract of Ocimum americanum recorded the lowest insecticidal potential. The toxicity difference and extraction solvent among test plants suggested that different plants have different phytochemicals, which can be extracted by different solvents.

High larval mortality of $95 \%$ was caused by ethanol leaf extract of Azadirachta indica. This finding is similar to the report of Okumu et al. [22] where hexane leaf extract of Azadirachta indica was found to cause $100 \%$ mortality against larvae of Anopheles gambiae at 1,000 ppm although the concentrations are different. This could be due to the presence of excess bioactive secondary metabolites [23].

However, this finding disagrees with findings of Vilayatakar et al. [24] that reported the aqueous extract of Moringa oleifera leaves against larvae of Anopheles had shown $60 \%$ mortality at $500 \mathrm{ppm}$. Similarly, acetone

Table $\mathbf{5}$ LC50 and LC90 of test plant leaf extracts against adult Anopheles arabiensis

\begin{tabular}{|c|c|c|c|c|c|c|c|c|}
\hline Solvent & Plant name & LC50 & $\mathrm{LCL}$ & UCL & LC90 & $\mathrm{LCL}$ & UCL & $X^{2}\left(d f^{b}=4\right)$ \\
\hline \multirow[t]{2}{*}{ Ethanol } & Azadirachta indica & 151.033 & 96.794 & 232.69 & 1059 & 486.47 & $20,498.55$ & 0.360 \\
\hline & Ocimum lamiifolium & 125.48 & 50.472 & 206.825 & 1468.15 & 526.74 & $88,685.0$ & 0.471 \\
\hline \multirow[t]{2}{*}{ Methanol } & Azadirachta indica & 106.655 & 30.232 & 168.537 & 1293 & 481.79 & 751,031 & 1.099 \\
\hline & Ocimum lamiifolium & 158.50 & 105.391 & 245.687 & 1054.1 & 491.37 & $17,355.7$ & 0.045 \\
\hline
\end{tabular}

*LC50-Lethal concentration kills $50 \%$ of the exposed adult

LC90-Lethal concentration kills $90 \%$ of the exposed adult

UCL Upper confidence limit

LCL Lower confidence limit

$X^{2}$ Chi-square

$d f$ degree of freedom 
Table 6 Phytochemical screening of methanol and ethanol crude extracts of test plants

\begin{tabular}{|c|c|c|c|c|c|c|c|}
\hline \multirow[t]{2}{*}{ Plant name } & \multirow[t]{2}{*}{ Solvent } & \multicolumn{6}{|c|}{ Secondary metabolite } \\
\hline & & Alkaloids & Flavonoids & Terpinoids & Tannin & Saponin & Phenols \\
\hline \multirow[t]{2}{*}{ Azadirachta indica } & Ethanol & + & + & + & + & + & + \\
\hline & Methanol & + & + & + & + & + & + \\
\hline \multirow[t]{2}{*}{ Ocimum lamiifolium } & Ethanol & + & - & + & + & + & + \\
\hline & Methanol & + & - & + & + & + & + \\
\hline \multirow[t]{2}{*}{ Ocimum americanum } & Ethanol & - & - & + & - & - & + \\
\hline & Methanol & - & - & + & - & - & + \\
\hline \multirow[t]{2}{*}{ Moringa olifeira leaf } & Ethanol & + & + & + & + & + & - \\
\hline & Methanol & + & + & + & + & + & + \\
\hline \multirow[t]{2}{*}{ Moringa olifeira seed } & Ethanol & + & + & + & - & - & - \\
\hline & Methanol & + & + & + & - & - & + \\
\hline
\end{tabular}

+ Present, - absent

extract of Ocimum lamiifolium oil was found to have high larvicidal activity against An. arabiensis [25]. Various factors might be responsible for the larvicidal activity, but the difference in larvicidal activities in the current finding could be due to locality of the plants, and different solvents.

Methanol leaf extract of Azadirachta indica causes adult mortality $75 \%$, which could be due to the presence of bioactive secondary metabolites. This finding is in line with the earlier finding of Kamaraj et al. [26], who reported adulticidal efficacy of methanol against Culex gelidus Theobald.

Ethanol leaf extract of Ocimum lamiifolium and Ocimum americanum was found to have 71.65 and $55 \%$ mortality, respectively, at $300 \mathrm{ppm}$ against adults of $A n$. arabiensis after $24 \mathrm{~h}$ exposure. This result is lower compared to the finding of Messebo et al. [27], where ethanol leaf extract of Ocimum lamiifolium showed 90\% mortality against adult An. arabiensis after $1 \mathrm{~h}$ exposure $0.25(\mathrm{v} / \mathrm{v})$ in other parts of Ethiopia. The difference in adulticidal activity in the current finding could be due to species of plants, extraction solvent, and locality of the plants.

\section{Conclusions}

Ethnobotanical plants are widely used in Dangur district, northwestern Ethiopia. Azadirachta indica, Ocimum lamiifolium, Ocimum americanum, Moringa olifeira leaf, and Moringa olifeira are plant species frequently used for mosquito prevention in northwest Ethiopia. They have effective larvicidal potential against fourth instar larvae of An. arabiensis. Ethanol leaf extract of Azadirachta indica has higher larvicidal potential and is promising for further botanical insecticide development. Ethanol and methanol extract of Azadirachta indica and
Ocimum lamiifolium have potential adulticidal activity with $>60 \%$ mortality against adult An. arabiensis. The phytochemical analysis of leaf extract of Azadirachta indica has secondary metabolites, such as alkaloid, flavonoid, terpenoid, tannin, saponin, and phenols, which have potential insecticidal activities. Further study is recommended to identify the active ingredient of ethanol and methanol extracts of Azadirachta indica and their mode of action in the study area and other parts of Ethiopia.

\section{Acknowledgements}

We thank Assosa University for funding. We are very grateful for the technical assistance of laboratory technicians of Tropical and Infectious Diseases Research Centre, Assosa University. We acknowledge the community of Dangur district, particularly key informants of the study villages.

\section{Authors' contributions}

AA conducted the laboratory work and interpreted the data and wrote the first draft of the manuscript. DE and AA designed the field collection protocols and oversaw the collection. DE provided a critical revision of the manuscript. All authors read and approved the final manuscript.

\section{Funding}

The funding for this work was obtained from Assosa University.

\section{Availability of data and materials}

The datasets used and/or analysed during the current study are available from the corresponding author on reasonable request.

\section{Declarations}

Ethics approval and consent to participate Not applicable.

Consent for publication

Not applicable.

\section{Competing interests}

The authors declare that they have no competing interests".

Received: 27 Auqust 2021 Accepted: 2 December 2021

Published online: 14 December 2021 


\section{References}

1. Kloos H, Zein ZA. The ecology of health and disease in Ethiopia. Westview Press; 1993.

2. Zein AZ. The ecology of health and disease in Ethiopia. Taylor \& Francis Group; 2021. p 540

3. Balkew M, Mumba P, Yohannes G, Abiy E, Getachew D, Yared S, et al. An update on the distribution, bionomics, and insecticide susceptibility of Anopheles stephensi in Ethiopia, 2018-2020. Malar J. 2021;20:263.

4. Yewhalaw D, Wassie F, Steurbaut W, Sponaghe P, Van Bortel W, Denis L, et al. Multiple insecticide resistance: an impediment to insecticide-based malaria vector control program. PLoS ONE. 2011;6:e16066.

5. Balkew M, Getachew A, Chibsa S, Olana D, Reithinger R, Brogdon W. Insecticide resistance a challenge to malaria vector control in Ethiopia. Malar J. 2012. https://doi.org/10.1186/1475-2875-11-S1-P139.

6. Hebbalkar YE, Temu EA, Amin E, Rayah E, Munga S, Kweka EJ. Chemical cues for malaria vectors oviposition site selection: challenges and opportunities. J Insects. 2013;1:9

7. Ejeta D. Ethno-botanical survey of plants used for prevention against mosquito bites and control of malaria in Assosa District, Western Ethiopia. Int J Ethnobiol Ethnomed. 2019:4:12.

8. Kweka EJ, Lima TC, Marciale CM, de Sousa DP. Larvicidal efficacy of monoterpenes against the larvae of Anopheles gambiae. Asian Pac J Trop Biomed. 2016;6:290-4

9. Karunamoorthi $\mathrm{K}$, llango K, Endale A. Ethnobotanical survey of knowledge and usage custom of traditional insect/mosquito repellent plants among the Ethiopian Oromo ethnic group. J Ethnopharmacol. 2009:125:224-9.

10. Karunamoorthi K, llango K. Larvicidal activity of Cymbopogon citratus (DC) Stapf. and Croton macrostachyus Del. against Anopheles arabiensis Patton, a potent malaria vector. Eur Rev Med Pharmacol Sci. 2010;14:57-62.

11. Martin GJ. Ethnobotany: a method manual. London: Chapman and Hall; 1995.

12. Hedberg I. Flora of Ethiopia and Eritrea. In: van der Maesen LJG, van der Burgt XM, van Medenbach de Rooy JM (eds) The Biodiversity of African Plants. Springer, Dordrecht; 1996. https://doi.org/10.1007/978-94-0090285-5_104.

13. Tomass Z, Hadis M, Taye A, Mekonnen Y. Larvicidal effects of Jatropha curcas L. against Anopheles arabiensis (Diptera: Culicidae). Momona. 2011;3:52-64.

14. WHO. Guidelines for laboratory and field testing of mosquito larvicides. Geneva: World Health Organization; 2005.

15. WHO. Guidelines for testing mosquitoes adulticides for indoor residual spraying and treatment of mosquito nets. Geneva: World Health Organization; 2006.

16. Madike LN, Takaidza S, Pillay M. Preliminary phytochemical screening of crude extracts from the leaves, stems, and roots of Tulbaghia violacea. Int J Pharmacogn Phytochem Res. 2017;9:1300-8.

17. Bandiola TMB. Extraction and qualitative phytochemical screening of medicinal plants: a brief summary. Int J Pharm. 2018;8:137-43.

18. Bekele D, Asfaw Z, Petros B, Tekie H. Ethnobotanical study of plants used for protection against insect bite and the treatment of livestock health problems in rural areas of Akaki District, Eastern Shewa. Ethiopia TopClass J Herb Med. 2012;1(suppl 2):12-24.

19. Kaliyaperumal K, Mulelam A, Wassie F. Assessment of knowledge and usage custom of traditional insect/mosquito repellent plants in Addis Zemen Town, South Gonder North Western Ethiopia. J Ethnopharmacol. 2008;121:49-53.

20. Karunamoorthi $K$, Hailu T. Insect repellent plants traditional usage practices in the Ethiopian malaria epidemic-prone setting: an ethnobotanical survey. J Ethnobiol Ethnomedicine. 2014;10:22.

21. Baana K, Angwech H, Malinga GM. Ethnobotanical survey of plants used as repellents against houseflies, Musca domestica L. (Diptera: Muscidae) in Budondo Subcounty, Jinja District. Uganda J Ethnobiol Ethnomed. 2018:14:1-8.

22. Okumu FO, Knols BGJ, Fillinger U. Larvicidal effects of a neem (Azadirachta indica) oil formulation on the malaria vector Anopheles gambiae. Malar J. 2007;6:63.

23. Kortbeek RWJ, van der Gragt M, Bleeker PM. Endogenous plant metabolites against insects. Eur J Plant Pathol. 2019;154:67-90.
24. Vilayatakar MB, Thakare VG. Study on larvicidal efficacy of Moringa oleifera against the vector Anopheles mosquitoes. BioSci Discov. 2018;9(suppl 3):365-70.

25. Fekadu M, Mekuria T, Tesfaye B, Meshesha B, Teshome G. Evaluation on larvicidal effects of essential oils of some local plants against Anopheles arabiensis Patton and Aedes aegypti Linnaeus (Diptera, Culicidae) in Ethiopia. Afr J Biotechnol. 2009;8:4183-8.

26. Kamaraj C, Rahuman AA, Mahapatra A, Bagavan A, Elango G. Insecticidal and larvicidal activities of medicinal plant extract against mosquitoes. Parasitol Res. 2010;107:1337-49.

27. Massebo F, Mekuria T, Balkew M, Gebre-Michael T. Bioactivity of essential oils of local plants against adult Anopheles arabiensis (Diptera: Culicidae) in Ethiopia. Adv Biosci Biotechnol. 2013;8:805-9.

\section{Publisher's Note}

Springer Nature remains neutral with regard to jurisdictional claims in published maps and institutional affiliations.
Ready to submit your research? Choose BMC and benefit from:

- fast, convenient online submission

- thorough peer review by experienced researchers in your field

- rapid publication on acceptance

- support for research data, including large and complex data types

- gold Open Access which fosters wider collaboration and increased citations

- maximum visibility for your research: over $100 \mathrm{M}$ website views per year

At BMC, research is always in progress.

Learn more biomedcentral.com/submissions 